\title{
QUALITY OF LIFE IN PATIENTS WITH MULTIPLE MYELOMA TREATED WITH PERCUTANEOUS VERTEBROPLASTY
}

\author{
CALIDAD DE VIDA EN PACIENTES CON MIELOMA MÚLTIPLE TRATADOS CON \\ VERTEBROPLASTIA PERCUTÁNEA
}

\section{QUALIDADE DE VIDA EM PACIENTES COM MIELOMA MÚLTIPLO TRATADOS COM VERTEBROPLASTIA PERCUTÂNEA}

OMAR JAMIT BOHSAIN ${ }^{1}$

\begin{abstract}
Objective: To determine the quality of life in patients with multiple myeloma treated with vertebroplasty. Multiple myeloma has a prevalence of $1 \%$ in all neoplastic diseases and $10 \%$ of hematological malignancies. Bone pain is the initial symptom in most cases. Methods: A series of cases study was conducted. Patients were assessed by the Karnofsky scale to measure its functionality, the WHO analgesic scale to assess the type of analgesic and visual analog scale (VAS) and the Oswestry questionnaire for pain. Results: Of 24 patients, 10 were cases (vertebroplasty) (41.7\%) and 14 were controls (conservative) (58.3\%), 13 (54.2\%) were female and 11 (45.8\%) male, with an average age of 60 years $(S D=12)$ and $63 \mathrm{~kg}$ of average weight $(\mathrm{SD}=12)$, mean height of $1.59 \mathrm{~cm}(\mathrm{SD}=9)$ and mean body mass index of 24.8 $(\mathrm{SD}=3.7)$. Survival was obtained from the time of diagnosis to death, and $2(8.3 \%)$ patients died within the first 2 years and $1(4.2 \%)$ after 3 years. Conclusions: Patients with MM who have vertebral fractures are excellent candidates to undergo vertebroplasty, because this represents a greater benefit in their quality of life, which has a direct impact on their level of functionality, giving them greater self-sufficiency and reducing their pain because of the benefits of the thermogenic effect of vertebroplasty.
\end{abstract}

Keywords: Multiple myeloma; Spine; Quality of life; Vertebroplasty.

\section{RESUMO}

Objetivo: Determinar a qualidade de vida em pacientes com mieloma múltiplo tratados com vertebroplastia. O mieloma múltiplo tem prevalência de $1 \%$ em todas as doenças neoplásicas e em 10\% das neoplasias hematológicas. A dor óssea é a manifestação inicial na maioria dos casos. Métodos: Foi realizado um estudo de série de casos. Os pacientes foram avaliados pela escala de Karnofsky para medir sua funcionalidade, pela escala analgésica da OMS para avaliar o tipo de analgésico e pela escala analógica visual (VAS) e o questionário de Oswestry para a dor. Resultados: Dos 24 pacientes, 10 eram casos (vertebroplastia) (41,7\%) e 14 controles (conservador) (58,3\%), 13 (54,2\%) do sexo feminino e 11 (45,8\%) masculino, com média de idade de 60 anos (DP = 12) e $63 \mathrm{~kg}$ de peso médio (DP = 12), estatura média de 1,59 cm (DP =9) e média de índice de massa corporal de 24,8 (DP = 3,7). A sobrevida foi obtida desde o momento do diagnóstico até a morte, sendo que 2 (8,3\%) pacientes morreram nos primeiros 2 anos e 1 (4,2\%), depois de 3 anos. Conclusões: Pacientes com MM que têm fraturas vertebrais são excelentes candidatos para realizar o procedimento de vertebroplastia, porque isso representa um maior benefício em sua qualidade de vida, que tem um impacto direto sobre seu nível de funcionalidade, dando-Ihes maior autossuficiência e reduzindo da dor pelos benefícios do efeito termogênico da vertebroplastia.

Descritores: Mieloma múltiplo; Coluna vertebral; Qualidade de vida; Vertebroplastia.

\section{RESUMEN}

Objetivo: Conocer la calidad de vida en pacientes con mieloma múltiple tratados con vertebroplastia. El mieloma múltiple tiene una prevalencia del 1\% de todas las enfermedades neoplásicas y el 10\% de las hemopatías malignas. Regularmente el dolor óseo es la manifestación inicial en la mayoría de los casos. Métodos: Se realizó un estudio de serie de casos. Los pacientes fueron evaluados por la escala de Karnofsky para medir su funcionalidad, la escala analgésica de la OMS para valorar el tipo de analgésico, la escala visual analógica (EVA) y el cuestionario de Oswestry para el dolor. Resultados: De los 24 pacientes, 10 fueron casos (vertebroplastia) (41,7\%) y 14 controles (conservador) (58,3\%), $13(54,2 \%)$ del sexo femenino y 11 (45,8\%) del sexo masculino, con edad promedio de 60 años (DS = 12), peso promedio de $63 \mathrm{Kg}$, (DS = 12), talla promedio de 1,59 cm (DS =9), y con índice de masa corporal promedio de 24,8 $(D S=3,7)$. Se obtuvo la sobrevivencia desde el momento del diagnostico hasta su muerte, siendo que 2 (8,3\%) fallecieron dentro de los 2 primeros años y 1 (4,2\%) después de los 3 años. Conclusiones: Los pacientes con MM que presentan fracturas vertebrales son excelentes candidatos para realizar el procedimiento de la vertebroplastia, ya que esto representa un mayor beneficio en su calidad de vida, lo cual repercute directamente en su nivel de funcionalidad, otorgándoles mayor autosuficiencia, disminuyendo el dolor por los beneficios del efecto termogénico de la vertebroplastia.

Descriptores: Mieloma múltiple; Columna vertebral; Calidad de vida; Vertebroplastia.

\section{INTRODUCTION}

Multiple myeloma (MM) represents $1 \%$ of all neoplasias and $10 \%$ of malignant hemopathies, with an annual incidence in our country of 3-4 new cases per 100,000 people. The average age of presentation is around 65 years, and it is rare in individuals younger than 30 years of age $(0.3 \%$ of all cases).

Only $12 \%$ are aged under 50 years of age, and only $2 \%$ are aged under 40 years. ${ }^{1}$

1. Orthopedics and Traumatology Service of the Centro Médico Nacional de Occidente, Instituto Mexicano del Seguro Social [Mexican Institute of Social Security], Guadalajara, Jalisco, Mexico.

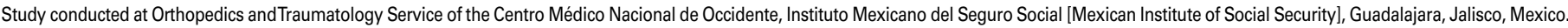
Correspondence: Belisario Domínguez No. 1000. Colonia Independencia. C.P. 44610, Guadalajara, Jalisco. Mexico. dromarjamit@gmail.com 
Differential diagnosis with Monoclonal Gammopathy of Undetermined Significance (MGUS), quiescent myeloma (QM), primary amyloidosis $(\mathrm{AL})$, and metastatic carcinoma is suggested. ${ }^{2}$

Bone pain is the initial symptom in 70 to $80 \%$ of the cases, usually located in the spine and ribs and with mechanical characteristics. ${ }^{1,2}$

The role of imaging studies in the treatment of MM includes assessment of the extent of the severity of the disease at presentation, and identification and characterization of complications, as well as the subsequent stage of the disease..$^{3-7}$

Compression fractures increase morbidity and mortality, causing spinal deformity and intractable pain. Clinical studies of vertebroplasty (VP) have reported a $90 \%$ reduction of pain, with minimal complications, which is relatively high. In a study in which VP was performed on 14 levels in 7 patients, pain was reduced by an average of $50 \%$ in 6 patients. ${ }^{8}$

Over the last five years, VP has rapidly become one of the techniques for spinal surgery. In recent years, the use of VP for the treatment of vertebral fractures has become very common. Several studies have documented the efficacy of VP in the relief of pain associated with acute or subacute compression fractures. ${ }^{9,10}$

Vertebroplasty is the treatment described as the internal augmentation of the fractured vertebra through an intraosseous infusion of bone cement, usually PMMA, into the vertebral body to reduce pain and provide stability.

Several theories have been proposed about pain relief following vertebroplasty. It is likely that one component of VP-related analgesia is a result of the immobility of the microfractures and the reduction of mechanical forces.

The destruction of nerve endings caused by cytotoxic, mechanical, and vascular effects and the effects of PMMA, as well as the thermal effects of polymerization, may also play a role in pain relief. It has also been proposed that PMMA has an antitumor effect, which may explain the rarity of local recurrence following VP.11,12

In $\mathrm{MM}$, when compression fractures cause intractable pain and do not respond to conservative treatment, VP is effective, improving quality of life and reducing pain, as well as reducing analgesic medications, improving mobility, and enabling a state of higher performance. ${ }^{12-14}$

Patients with $\mathrm{MM}$ are excellent candidates for this procedure. VP can be a safe and effective procedure in patients with fractures of the vertebral body caused by $\mathrm{MM}^{15}$

The objective is to stabilize the fracture, reducing pain in the spinal column, and decrease the ingestion of analgesics, as well as changing the type of analgesic taken. It is important to continue to conduct this type of analytical study, which gives evidence-based results.

\section{MATERIAL AND METHODS}

The records from the archives of the Centro Médico Nacional de Occidente Lic. Ignacio García Téllez hospital in Guadalajara, Jalisco, of the patients who had the hematological disorder multiple myeloma (MM), treated conservatively and surgically with vertebroplasty, were reviewed.

Patients of both sexes and any age were included, diagnosed with MM according to the criteria of the International Myeloma Working Group and who underwent vertebroplasty for the treatment of spinal fractures, regardless of the amount of time elapsed since the procedure, or who were treated conservatively, as well as patients in any stage of MM and with any comorbidity. Patients with any other pathology, who did not meet the diagnostic criteria of the International Myeloma Working Group, or those who were lost during follow-up and could not be located for evaluation, were not included.

A data collection form was prepared containing variables such as the different classifications used - the Visual Analog Scale, Karnofsky, Oswestry, and the WHO analgesic scale - with the goal of being able to apply them to patients with MM who underwent vertebroplasty, which was defined as the case group, and to the control group consisting of patients with MM and spinal fractures who underwent conservative treatment.
The data capture form contained data from the clinical worksheet; type of treatment performed, whether radiotherapy, chemotherapy, conservative management, or vertebroplasty surgery; and whether the Karnofsky scale, the visual analog scale, the WHO analgesic scale, or the Oswestry questionnaire were used to assess the quality of life and pain.

The Karnofsky scale assesses a patient's ability to perform daily activities on a scale of 0 to 100 . Patients with a score of 80-100 are rated good, of 50-70 fair, of 20-40 poor, of 10 dying, and of 0 dead.

The WHO analgesic scale evaluates whether the type of analgesic used is a non-opioid, a mild opioid, or a strong opioid.

The visual analog scale (VAS) assesses the intensity of pain on a scale of 0 to 10

The Oswestry questionnaire rates the patient's degree of disability as poor for a score of 31-50, fair for a score of 21-30, and good for a score of 0-20.

Survival was evaluated on a score of 0 to 3 , considering the entire time span from the MM diagnosis to the current evolution or up until death, in the case of patients who died following the interviews.

The results were compiled after the interview and the application of the various scales directly to the patients, in both the cases and the control groups.

The results were compiled from the evaluation conducted at the time of the appointment, after which the information was coded, tabulated and analyzed using the computer software (EPi Info Ver. 3.5.1 and SPSS Ver. 10.0), in which the absolute and relative frequencies and the central tendency, dispersion, and association measures (OR) were recorded.

\section{RESULTS}

A total of 24 patients, diagnosed with multiple myeloma (MM) met the inclusion criteria and underwent either vertebroplasty of the spinal column or conservative treatment between January 2007 and December 2011, were studied. (Figure 1)

The group consisted of 24 patients, 10 of whom were cases (vertebroplasty) (41.7\%) and 14 of whom were controls (conservative treatment) $(58.3 \%)$. Thirteen patients $(54.2 \%)$ were female and 11 were male (45.8\%), with an average age of 60 with a standard deviation of 12 , an average weight of $63 \mathrm{~kg}$ with a standard deviation of 12 , an average height of $1.59 \mathrm{~m}$ with a standard deviation of $9 \mathrm{~cm}$, and an average BMl of 24.81 with a standard deviation of 3.71. (Table 1)

The laboratory tests reported an average $\mathrm{Hb}$ of 117 with a standard deviation of 2.57, HTC of 35.08 with a standard deviation of 7.86 , leukocyte count of 6.0 with a standard deviation of 3.5, platelet count of 206,375 with a standard deviation of 48,104 , an average erythrocyte count of 3.76 with a standard deviation of 0.77 , creatinine with an average of 1.27 and standard deviation of 1.51 , and calcium with an average of 9.18 and standard deviation of 1.15. (Table 1)

Radiographical studies of the vertebral fractures were categorized

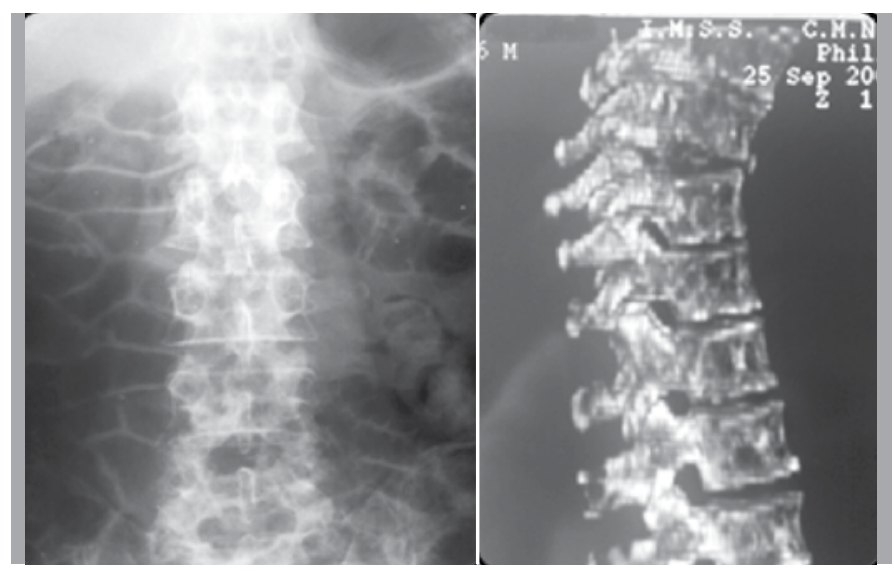

Figure 1. Male, 63 years of age, with Dx of multiple myeloma with multiple vertebral fractures at the thoracic and lumbar levels. 
into three groups depending on the number of fractures presented by each patient, with a value of 1 for up to 2 fractures, 2 for up to 4 fractures, and 3 for more than 4 fractures. There were 10 patients $(41.66 \%)$ in group 1, 8 (33.3\%) in group 2, and $6(25 \%)$ in group 3. Lytic skull lesions were found in 19 patients (79.16\%). (Figure 2)

As regards the physical conditions of the patients, $22(91.7 \%)$ experienced weight loss, 7 (29.2\%) drank alcohol while 17 (70.8\%) did not, 4 (16.7\%) were smokers and 20 (83.3\%) were non-smokers, none of the patients were drug users, $5(20.8 \%)$ had high blood pressure, $4(16.7 \%)$ had kidney failure, 1 (4.2\%) had facial paralysis, and 14 (58.3\%) had no concomitant diseases.

Among the medical treatments performed, 22 (91.7\%) patients received chemotherapy and $2(8.3 \%)$ did not, use of analgesics was negative for $2(8.3 \%)$ patients and positive in $22(91.7 \%)$, of whom $9(37.5 \%)$ reported the use of non-opioid analgesics, $4(16.7 \%)$ the use of mild opioids, and $11(45.8 \%)$ the use of strong opioids.

As regards the scales applied, the VAS scores reported were 1 patient with a score of 1 (4.2\%), 2 with $3(6.3 \%), 5$ with $4(20.5 \%)$, 3 with 5 (12.5\%), 1 with $6(4.2 \%), 4$ with $7(16.7 \%), 2$ with $8(8.3 \%)$, 4 with 9 (16.7\%), and 2 with $10(8.3 \%)$; the Oswestry scale for evaluation of the level of patient disability reported 8 patients as good (33.4\%), 5 as fair (20.8\%), and 11 as poor (45.8\%); and the Karnofsky scale to assess the patient's performance of daily tasks reported 4 patients as good (16.7\%), 12 as fair (50\%), and 8 as poor (33.3\%). In terms of survival, measured from the time of diagnosis until death, 2 patients (8.3\%) were reported as deceased within the first 2 years following diagnosis and 1 (4.2\%) after 3 years.

An inferential analysis was performed to evaluate various risk factors among the patients with vertebroplasty vs. those with conservative treatment. These included age, with a reference point defined as greater than 60 , which yielded $\mathrm{OR}=0.5(\mathrm{Cl} 95 \%$ 0.07-3.45) and $p>0.05$. The use of analgesics showed a probability of using use of non-opioid analgesics of $50 \%$ in the VP group in comparison to the control group ( $\mathrm{Cl} 95 \%$ 0.07-4.25) and $\mathrm{p}>0.05$. Concomitant diseases yielded $O R=1(\mathrm{Cl} 95 \% 0.38-2.66)$ and $p>0.05$. The results of the Oswestry questionnaire for the degree of disability were regrouped into two groups, good and poor, with a 3 times greater probability of a good result with VP $(\mathrm{Cl} 95 \% 0.42-25.22)$ and $\mathrm{p}>0.05$, when compared with the conservatively treated control group. The Karnofsky

Table 1. Demographic data for multiple myeloma

\begin{tabular}{|c|c|c|c|c|c|c|}
\hline Variables & & Abs. Freq. & Rel. Freq. & Variables & Average & SD \\
\hline \multirow[t]{2}{*}{ Sex } & Female & 13 & $54.20 \%$ & Age & 60.0 & 12.0 \\
\hline & Male & 11 & $45.80 \%$ & Weight & 63.7 & 12.3 \\
\hline \multirow[t]{2}{*}{ Weight loss } & Yes & 22 & $91.70 \%$ & Height & 1.6 & 9.0 \\
\hline & No & 2 & $8,30 \%$ & $\mathrm{BMI}$ & 24.8 & 3.7 \\
\hline \multirow[t]{2}{*}{ Alcohol Use } & Yes & 7 & $29.20 \%$ & $\mathrm{Hb}$ & 11.7 & 2.8 \\
\hline & No & 17 & $70,80 \%$ & $\mathrm{HTC}$ & 35,1 & 7,9 \\
\hline \multirow[t]{2}{*}{ Smoking } & Yes & 4 & $16.70 \%$ & Erythrocytes & 3.8 & 0.8 \\
\hline & No & 20 & $83,30 \%$ & Platelets & $206,000.0$ & $48,000.0$ \\
\hline \multirow[t]{2}{*}{ Drugs } & Yes & 0 & $0.00 \%$ & Leukocytes & 6.0 & 3.5 \\
\hline & No & 24 & $100.00 \%$ & Creatinine & 1.3 & 1.5 \\
\hline Concomitant & $\mathrm{SAH}$ & 5 & $20.80 \%$ & Calcium & 9.2 & 1.2 \\
\hline \multirow[t]{3}{*}{ diseases } & $\mathrm{CRI}$ & 4 & $16.70 \%$ & VCF & 4.0 & 8.0 \\
\hline & \begin{tabular}{|c|} 
Facial \\
Paralysis \\
\end{tabular} & 1 & $4.20 \%$ & & & \\
\hline & None & 14 & $58.30 \%$ & & & \\
\hline \multirow[t]{2}{*}{ Chemotherapy } & Yes & 22 & $91.70 \%$ & & & \\
\hline & No & 2 & $8.30 \%$ & & & \\
\hline \multirow[t]{2}{*}{ Radiotherapy } & Yes & 10 & $41.70 \%$ & & & \\
\hline & No & 14 & $58.30 \%$ & & & \\
\hline \multirow[t]{2}{*}{$\begin{array}{c}\text { Use of } \\
\text { Analgesic }\end{array}$} & Yes & 22 & $91.70 \%$ & & & \\
\hline & No & 2 & $8.30 \%$ & & & \\
\hline \multirow[t]{2}{*}{$\begin{array}{c}\text { Type of } \\
\text { Analgesic }\end{array}$} & $\begin{array}{l}\text { Non- } \\
\text { opioid }\end{array}$ & 9 & $37.50 \%$ & & & \\
\hline & No & 5 & $20.84 \%$ & & & \\
\hline
\end{tabular}

questionnaire for the performance of daily tasks, also regrouped into good and poor, showed $70 \%$ good results with VP compared with the control group (Cl 95\% 0.08-4.52). The Oswestry questionnaire showed the probability of good results in males to be 2 times higher than in females $(\mathrm{Cl} 95 \%$ 0.3-14.79) and $\mathrm{p}>0.05$. (Table 2)

\section{DISCUSSION}

Multiple myeloma (MM) is an incurable disease, even with the best medical treatments including chemotherapy and radiotherapy, which affects men and women with an average age of 60 years in similar proportion.

In patients with MM who presented vertebral fractures, it was observed that vertebroplasty, when compared with conservative treatment, enabled a change in the use of analgesics from opioids to non-opioids in up to $57 \%$, and improved the symptoms of pain.

The degree of disability was also assessed in both groups using the Oswestry questionnaire, and a probability of good results three times higher in the VP group than in the control group was obtained. Also, $70 \%$ of the patients who underwent percutaneous vertebroplasty received good results from the Karnofsky questionnaire for the performance of daily tasks.

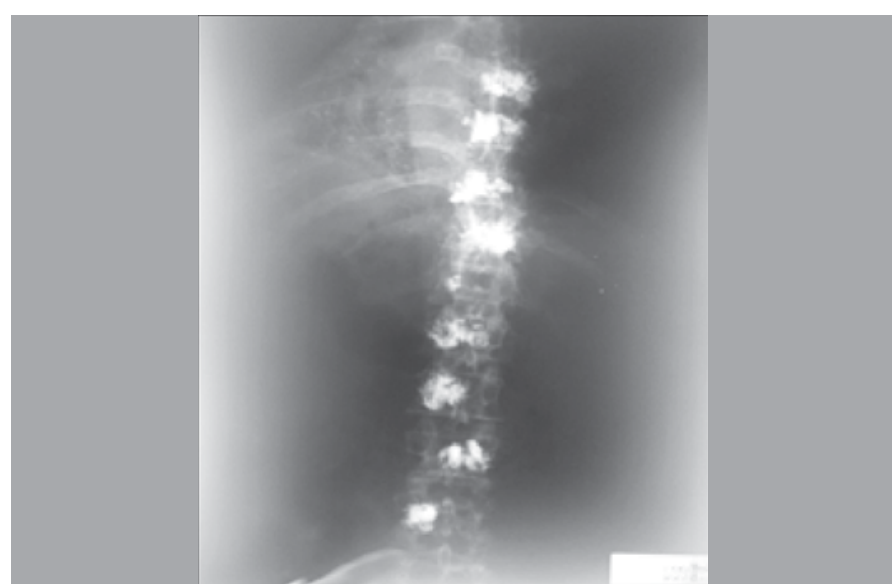

Figure 2. Post vertebroplasty surgery of multiple levels in T8- T12 and L2-L5.

Table 2. Distribution of variables for the evaluation of quality of life.

\begin{tabular}{c|c|c|c|c|c|c|c}
\hline Variables & & $\%$ & & $\%$ & OR & Cl 95\% & p \\
\hline Age & $>60$ & $\%$ & $<59$ & $\%$ & & & \\
\hline VP & 4 & $40.0 \%$ & 6 & $60.0 \%$ & 0.5 & $0.07-3.45$ & $>0.05$ \\
\hline Conservative & 8 & $57.1 \%$ & 6 & $42.9 \%$ & 1 & & \\
\hline $\begin{array}{c}\text { Use of } \\
\text { Analgesic }\end{array}$ & Non-opioid & $\%$ & Opioid & $\%$ & & & \\
\hline VP & 3 & $30.0 \%$ & 7 & $70.0 \%$ & 0.57 & $0.07-4.25$ & $>0.05$ \\
\hline Conservative & 6 & $42.9 \%$ & 8 & $57.1 \%$ & 1 & & \\
\hline $\begin{array}{c}\text { Concomitant } \\
\text { Diseases }\end{array}$ & SAH & $\%$ & CRI & $\%$ & & & \\
\hline VP & 4 & $66.6 \%$ & 2 & $33.3 \%$ & 1 & $0.38-2.66$ & $>0.05$ \\
\hline Conservative & 2 & $66.7 \%$ & 1 & $33.3 \%$ & 1 & & \\
\hline Oswestry & Good & $\%$ & Poor & $\%$ & & & \\
\hline VP & 7 & $70.0 \%$ & 3 & $30.0 \%$ & 3.11 & $0.42-25.22$ & $>0.05$ \\
\hline Conservative & 6 & $57.1 \%$ & 8 & $42.9 \%$ & 1 & & \\
\hline Karnofsky & Good & $\%$ & Poor & $\%$ & & & \\
\hline VP & 8 & $80.0 \%$ & 2 & $20.0 \%$ & 3 & $0.35-30.52$ & $>0.05$ \\
\hline Conservative & 8 & $57.1 \%$ & 6 & $42.9 \%$ & 1 & & \\
\hline VAS & $>5$ & $\%$ & $<5$ & $\%$ & & & \\
\hline VP & 6 & $60.0 \%$ & 4 & $40.0 \%$ & 0.6 & $0.08-4.52$ & $>0.05$ \\
\hline Conservative & 10 & $71.4 \%$ & 4 & $28.6 \%$ & 1 & & \\
\hline Sex & Male & $\%$ & Female & $\%$ & & & \\
\hline Oswestry+ & 7 & $63.6 \%$ & 6 & $46.2 \%$ & 2.04 & $0.3-14.79$ & $>0.05$ \\
\hline Oswestry- & 4 & $36.4 \%$ & 7 & $63.6 \%$ & 1 & & \\
\hline & & \multicolumn{7}{|c|}{$\%$} & &
\end{tabular}


Another factor evaluated was the Oswestry disability questionnaire between male and female patients, where the probability of good results was observed to be two times greater in male patients.

Thus, based on this study, patients with MM who have vertebral fractures are excellent candidates for undergoing the vertebroplasty procedure, as it offers greater benefits in terms of their quality of life, which directly affects their degree of functionality, as well as how they perform their daily tasks, offering greater self-sufficiency and reducing pain through the benefits conferred by the thermogenic effect of vertebroplasty.

\section{CONCLUSION}

Multiple myeloma is a disease that accounts for $10 \%$ of all pathologies included in the Vertebral Destruction Syndrome (VDS), manifesting itself as vertebral fractures that cause instability of the spinal column, and sometimes as radicular affectations and medullary compression. Patients who have MM with vertebral fractures are excellent candidates for undergoing the vertebroplasty procedure, which offers benefits for their quality of life and directly impacts their degree of functionality, enabling greater self-sufficiency, since their pain is reduced.

Because it is a minimally invasive procedure, complications that can result from open surgery are eliminated, no overnight stay in the hospital is required, and recovery is rapid.

Patients usually go home the same day as the treatment and they have immediate relief from or elimination of pain within 48 hours.

Vertebroplasty can be considered a procedure that offers greater benefits for the quality of life of these patients, and has a direct impact on their degree of functionality, and therefore, their quality of life.

All authors declare no potential conflict of interest concerning this article.

\section{REFERENCES}

1. Almaguer DG. Guías Mexicanas de diagnóstico y recomendaciones terapéuticas para mieloma múltiple. Hematología. 2010;11(1):40-62.

2. Rajkumar SV. Multiple myeloma: 2011 update on diagnosis, risk-stratification, and management. Am J Hematol. 2011;86(1):57-65.

3. D'Sa S, Abildgaard N, Tighe J, Shaw P, Hall-Craggs M. Guidelines for the use of imaging in the management of myeloma. Br J Haematol. 2007;137(1):49-63.

4. Mahnken AH, Wildberger JE, Gehbauer G, Schmitz-Rode T, Blaum M, Fabry U, et al. Multidetector CT of the spine in multiple myeloma: comparison with MR imaging and radiography. AJR Am J Roentgenol. 2002;178(6):1429-36.

5. Zha Y, Li M, Yang J. Dynamic contrast enhanced magnetic resonance imaging of diffuse spinal bone marrow infiltration in patients with hematological malignancies. Korean $\mathrm{J}$ Radiol. 2010;11(2):187-94.

6. Hillengass $J$, Wasser $K$, Delorme $S$, Kiessling F Zechmann $C$, Benner $A$, et al. Lumbar bone marrow microcirculation measurements from dynamic contrast-enhanced magnetic resonance imaging is a predictor of event-free survival in progressive multiple myeloma. Clin Cancer Res. 2007;13(2 Pt 1):475-81.

7. Rahmouni A, Divine M, Mathieu D, Golli M, Haioun C, Dao T, et al. MR appearance of multiple myeloma of the spine before and after treatment. AJR Am J Roentgenol. 1993;160(5):1053-7.
8. Diamond TH, Hartwell T, Clarke W, Manoharan A. Percutaneous vertebroplasty for acute vertebral body fracture and deformity in multiple myeloma: a short report. $\mathrm{Br} \mathrm{J}$ Haematol. 2004:124(4):485-7.

9. Kallmes DF, Jensen ME. Percutaneous vertebroplasty. Radiology. 2003;229(1):27-36

10. Kaufmann TJ, Jensen ME, Schweickert PA, MarxWF, Kallmes DF. Age of fracture and clinical outcomes of percutaneous vertebroplasty. AJNR Am J Neuroradiol. 2001;22(10):1860-3.

11. Lim BS, Chang UK, Youn SM. Clinical outcomes after percutaneous vertebroplasty for pathologic compression fractures in osteolytic metastatic spinal disease. J Korean Neurosurg Soc. 2009;45(6):369-74.

12. Cortet B, Cotten A, Boutry N, Dewatre F, Flipo RM, Duquesnoy B, et al. Percutaneous vertebroplasty in patients with osteolytic metastases or multiple myeloma. Rev Rhum Engl Ed. 1997;64(3):177-83.

13. Köse KC, Cebesoy O, Akan B, Altinel L, Dinçer D, Yazar T. Functional results of vertebra augmentation techniques in pathological vertebral fractures of myelomatous patients. $J$ Natl Med Assoc. 2006;98(10):1654-8.

14. Garland P, Gishen P, Rahemtulla A. Percutaneous vertebroplasty to treat painful myelomatous vertebral deposits-long-term efficacy outcomes. Ann Hematol. 2011:90(1):95-100.

15. Yamazaki E, Takemura S, Sakamoto H, Bandai H, Mitsuoka H, Bandoh K, et al. [Efficacy of percutaneous vertebroplasty for multiple myeloma]. Rinsho Ketsueki. 2007;48(3):200-3. 